\title{
Discovering the Archaeologists of the World
}

\author{
Kenneth Aitchison, York Archaeological Trust and Landward \\ Research Ltd, 312 Baltic Quay, 1 Sweden Gate, London, SE16 7TJ, UK \\ E-mail: kenneth.aitchison@landward.eu
}

\begin{abstract}
Discovering the Archaeologists of Europe 2014 has shown that measuring archaeologists' capabilities is a tool that can be used to plan for the development of the profession, development that is necessary to enhance to protection and interpretation of the global archaeological resource.
\end{abstract}

Résumé: Le projet À la découverte des archéologues en Europe 2014 a montré que l'évaluation du potentiel des archéologues peut permettre de prévoir l'évolution de la profession, évolution qui est nécessaire pour améliorer la protection et l'interprétation des ressources archéologiques mondiales.

Resumen: Descubriendo a los arqueólogos de Europa 2014 ha mostrado que medir las capacidades de los arqueólogos es una herramienta que puede ser utilizada para planificar el desarrollo de la profesión, desarrollo que es necesario para mejorar la protección e interpretación de los recursos arqueológicos mundiales.

\section{KEY WORDS}

Capacity building, Professional archaeology, Practice, Education

This special issue of Archaeologies contains a series of articles that have all been written by contributors to the Discovering the Archaeologists of Europe 2014 project, a two-year transnational exercise that involved 23 organisations across 21 European countries. These organisations-university archaeology departments, national museums, state heritage agencies, private companies, professional associations, research institutes and charitable non-governmental organisations-worked together to map professional archaeology and its needs in the aftermath of the global economic crisis. Part-funded by the European Commission and coordinated by the York Archaeological Trust, this project (the results of which are published as Aitchison et al. 2014) has been a massive exercise, aiming to collect data 
from the employers of the estimated 25,000 professional archaeologists working in those countries.

The project reports (there are national reports for each of the 21 countries, published in English and in national languages at www.discoveringarchaeologists.eu) focus on issues relating to skills losses and training, but also cover workforce size, the profession's distribution between private and public sectors, academia and cultural resource management, qualifications and salaries.

The papers given here either draw upon data produced by that project, combining and comparing it with other datasets to explore economically and politically sensitive issues, beginning with the response to the economic crash of 2008 that eliminated a third or more archaeological jobs in countries like Ireland or Spain (Cleary et al.), or the future of a profession in which the majority of workers are now women (Lazar et al.).

Andrew Lawler enters into the depth of how archaeological practice can be undertaken in the post-modern state of Bosnia \& Herzegovina, where competing ethnic, linguistic and cultural identities in the present day affect the interpretation of human life in the past, while Katharina Möller asks whether archaeologists can freely move from country to country to live and work, as Article 45 of the Consolidated Version of the Treaty on the Functioning of the European Union (European Union 2012) should allow archaeologists from the $27 \mathrm{EU}$ states to do?

And, partly inspired by his work on the UK national component of the Discovering the Archaeologists of Europe 2014, Doug Rocks-Macqueen has undertaken a time-series analysis of advertisements for archaeological posts to explore the changing nature of the labour market in commercial, cultural resource management archaeology in the United States.

The Discovering the Archaeologists of Europe project emerged from a lengthy history of archaeology labour market intelligence projects in the UK and elsewhere in Europe, a sociology of professional archaeology that has coincided with political and economic developments across the discipline since the 1990s.

But what are the reasons for doing this kind of work? Is it just stamp collecting, an introspective epistemology of ourselves which has no value to the outside world? To take that attitude would be to devalue archaeology as a whole; knowing about the professionals who identify, interpret, curate and manage the physical remains of the human past allows those professionals to be supported, their needs to be identified and nurtured to lead to better protection for the archaeological heritage in the future.

This is more than a social science, this is capacity building —establishing and reinforcing an archaeological sector that can record, curate and so protect a dwindling cultural and environmental resource in the face of ongoing global economic and environmental changes. ICOMOS (2013) sees the 
development of people as a tool that enhances protection of the historic environment: "Capacity Building through education and training refers to strengthening the knowledge, abilities, skills, and attitudes of people with direct or indirect responsibilities for heritage conservation and management.", while to the United Nations' agencies, skills, experience and knowledge are the building blocks of individual performance, which can be acquired formally through education and training, and informally through doing and observing and which lead to social and economic change.

The United Nations Development Programme defines capacity building as "The process through which individuals, organisations and societies obtain, strengthen and maintain the capabilities to set and achieve their own development objectives over time" (UNDP 2009:5)

The UNDP model sees this process as best carried out through a five stage capacity development process, which includes measurement both before and after capacity development programmes are implemented. The predecessor Discovering the Archaeologists of Europe project collected data in twelve countries in 2008, just before the onset of the global financial crisis, and the cycle has now recorded what the crisis has done-giving individual archaeologists, employers, educators and policy-makers data to work with as they plan for the future.

The value of this model has led to discussion of a potential Discovering the Archaeologists of the Americas project, collecting and sharing information for professional archaeology in every country in South, Central, Caribbean and North America (Majewski 2014), and this could all combine with further cycles of national or regional projects to be part of an ongoing macro-project, a Discovering the Archaeologists of the World that can identify and support professional archaeological practice and education globally.

\section{References}

Aitchison, K., R, Alphas., V, Ameels., M, Bentz., C, Bors., E, Cella., K, Cleary., C, Costa., P, Damian., M, Diniz., C, Duarte., J, Frolík., C, Grilo., Initiative for Heritage Conservancy., N, Kangert., R, Karl., A, Kjærulf Andersen., V, Kobrusepp., T, Kompare., E, Krekovič., M, Lago da Silva., A, Lawler., I, Lazar., K, Liibert., A, Lima., G, MacGregor., N, McCullagh., M, Mácalová., A, Mäesalu., M, Malińska., A, Marciniak., M, Mintaurs., K, Möller., U, Odgaard., E, Parga-Dans., D, Pavlov., V, Pintarič Kocuvan., D, Rocks-Macqueen., J, Rostock., J, Pedro Tereso., A, Pintucci., E.S, Prokopiou., J, Raposo., K, Scharringhausen., T, Schenck., M, Schlaman., J, Skaarup., A, Šnē., D, Staššíková-Štukovská., I, Ulst., M, van den Dries., H, van Londen., R, Varela-Pousa., C, Viegas., A, Vijups., N, Vossen., T, Wachter., and L, Wachowicz.

2014. Discovering the Archaeologists of Europe 2012-2014: Transnational Report. http://www.discovering-archaeologists.eu/national_reports/2014/ transnational_report.pdf. Accessed 19th October 2014. 
EU (European Union).

2012. Consolidated Versions of the Treaty on European Union and the Treaty on the Functioning of the European Union. http://eur-lex.europa.eu/legalcontent/EN/TXT/PDF/?uri=CELEX:12012E/TXT\&from=EN. Accessed 15th October 2014.

ICOMOS (International Council on Monuments and Sites).

2013. Principles for Capacity Building through Education and Training in Safeguarding and Integrated Conservation of Cultural Heritage. http://cif. icomos.org/pdf_docs/CIF\%20Meetings/Guidelines/ICOMOS_CIF_Principles Capacity_EN_20130930.pdf. Accessed 19th October 2014.

Majewski, T.

2014. The Discovering the Archaeologists of the Americas Initiative. Paper presented at European Association of Archaeologists Annual Meeting, Istanbul, 11 September 2014.

UNDP (United Nations Development Programme).

2009. Capacity Development: a UNDP Primer. www.undp.org/content/dam/aplaws/ publication/en/publications/capacity-development/capacity-developmenta-undp-primer/CDG_PrimerReport_final_web.pdf. Accessed 19th October 2014. 